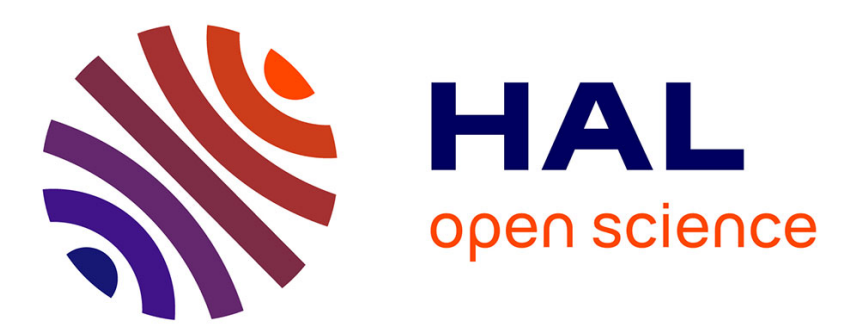

\title{
Short-range order in synthetic aluminous tremolites: An infrared and triple-quantum MAS NMR study
}

\author{
Franck C. Hawthorne, Mark D. Welch, Giancarlo Della Ventura, Shuangxi \\ Liu, Jean-Louis Robert, David M. Jenkins
}

\section{- To cite this version:}

Franck C. Hawthorne, Mark D. Welch, Giancarlo Della Ventura, Shuangxi Liu, Jean-Louis Robert, et al.. Short-range order in synthetic aluminous tremolites: An infrared and triple-quantum MAS NMR study. American Mineralogist, 2000, 85, pp.1716-1724. hal-00077541

\section{HAL Id: hal-00077541 \\ https://hal-insu.archives-ouvertes.fr/hal-00077541}

Submitted on 31 May 2006

HAL is a multi-disciplinary open access archive for the deposit and dissemination of scientific research documents, whether they are published or not. The documents may come from teaching and research institutions in France or abroad, or from public or private research centers.
L'archive ouverte pluridisciplinaire HAL, est destinée au dépôt et à la diffusion de documents scientifiques de niveau recherche, publiés ou non, émanant des établissements d'enseignement et de recherche français ou étrangers, des laboratoires publics ou privés. 


\title{
Short-range order in synthetic aluminous tremolites: An infrared and triple-quantum MAS NMR study
}

\author{
Frank C. HaWthorne, ${ }^{1, *}$ Mark D. Welch, ${ }^{2}$ Giancarlo Della Ventura,${ }^{3, \dagger}$ Shuangxi LiU, ${ }^{4}$ \\ JEAN-LOUIS ROBERT, ${ }^{5}$ AND DAVID M. JENKINS ${ }^{6}$
}

\author{
${ }^{1}$ Department of Geological Sciences, University of Manitoba, Winnipeg, Manitoba, R3T 2N2, Canada \\ ${ }^{2}$ Department of Mineralogy, The Natural History Museum, Cromwell Road, London SW7 5BD, U.K. \\ ${ }^{3}$ Dipartimento di Scienze Geologiche, Università di Roma Tre, Largo San Leonardo Murialdo 1, I-00146 Rome, Italy \\ ${ }^{4}$ Department of Chemistry, Nankai University, Tiannjin 300071, China \\ ${ }^{5}$ Centre de Recherche sur la Synthese et Chimie des Minéraux, CNRS, 1a rue de la Férollerie, 45071 Orleans Cedex 2, France \\ ${ }^{6}$ Department of Geological and Environmental Sciences, State University of New York at Binghamton, Binghamton, New York 13902-6000, \\ U.S.A.
}

\begin{abstract}
Fourier-transform infrared spectra (FTIR) were recorded on a series of synthetic amphiboles along the join $\mathrm{Ca}_{1.8} \mathrm{Mg}_{5.2} \mathrm{Si}_{8} \mathrm{O}_{22}(\mathrm{OH})_{2}-\mathrm{Ca}_{1.8}\left(\mathrm{Mg}_{4.2} \mathrm{Al}\right)\left(\mathrm{Si}_{7} \mathrm{Al}\right) \mathrm{O}_{22}(\mathrm{OH})_{2}$. The spectra were fitted by up to six component bands by optimization and non-linear least-squares techniques. ${ }^{27} \mathrm{Al}$ MAS NMR and triple-quantum (3Q) MAS NMR spectra were recorded for the synthetic amphibole $\mathrm{Ca}_{1.8}\left(\mathrm{Mg}_{4.8} \mathrm{Al}_{0.4}\right)\left(\mathrm{Si}_{7.6} \mathrm{Al}_{0.4}\right) \mathrm{O}_{22}(\mathrm{OH})_{2}$. The fitted FTIR and NMR spectra show that ${ }^{\mathrm{V}} \mathrm{Al}$ occurs at the M2 site and at the M1 or M3 sites; by analogy with previous crystal-structure refinement results on natural amphiboles, ${ }^{\mathrm{V}} \mathrm{Al}$ occupancy of $\mathrm{M} 2$ and $\mathrm{M} 3$ is presumed. The fine structure present in the FTIR spectra indicates that they are also affected by NNN (next-nearest-neighbor) interactions. There are two types of NNN arrangements: (1) SiSi or SiAl at adjacent T1T1 dimers; (2) permutation of $\mathrm{Mg} / \mathrm{Al}$ over M2M2M3 sites. Discounting those arrangements unlikely on bond-valence grounds, there are two arrangements that give rise to five distinct bands in the infrared spectra. There are two principal conclusions: (1) infrared spectra of amphiboles in the principal $\mathrm{OH}$-stretching region can be affected significantly by NNN effects; (2) the small number of bands due to NNN effects indicates that amphiboles show strong short-range order.
\end{abstract}

\section{INTRODUCTION}

The composition of calcic amphiboles, and the $\mathrm{Al}$ content in particular, has great potential in geobarometry of igneous and metamorphic processes. Both field evidence and experimental work suggest that $\mathrm{Al}$ content is correlated with the physical conditions $(P$ and $T)$ of amphibole formation (e.g., Spear 1981; Hammarstrom and Zen 1986; Hollister et al. 1987). This, together with the fact that amphiboles are ubiquitous in many geological environments (Hawthorne 1983), has prompted increased attention directed toward a more quantitative definition of Al solubility in both natural (Holland and Richardson 1979; Tribolet and Audren 1988; Kohn and Spear 1990; Mader and Berman 1992) and synthetic amphiboles (Jenkins 1988, 1994; Cho and Ernst 1991; Smelik et al. 1994). Two main problems have been encountered in these studies: (1) identifying the exchange reactions responsible for $\mathrm{Al}$ incorporation in the amphibole structure: in calcic amphiboles, there is general consensus in considering the tschermak substitution as the main

\footnotetext{
*E-mail: frank_hawthorne@umanitoba.ca

$\dagger$ Current address: Dipartimento di Scienze della Terra, Università della Calabria, I-87036 Rende (CS), Italy.
}

mechanism whereby one divalent cation and one Si are replaced by $\mathrm{Al}$ in both octahedral and tetrahedral coordination. (2) Thermodynamic modeling has been largely based on mixing models which did not take into account possible patterns of long-range order (LRO) and short-range order (SRO) involving substituting cations over non-equivalent sites. Most thermodynamic analyses have considered activity models based solely on $\mathrm{Mg} / \mathrm{Al}$ ordering at $\mathrm{M} 2$ and $\mathrm{Si} / \mathrm{Al}$ ordering at $\mathrm{T} 1$. Recent crystal-structure work has shown that these mixing models are inadequate. Long-range ordering patterns of $\mathrm{Al}$ in amphiboles are now quite well understood (Oberti et al. 1995a, 1995b), but we still know very little about SRO of Al. Infrared spectroscopy has potential with respect to SRO characterization in silicates, and there has been considerable effort recently to develop procedures to quantify SRO in synthetic amphiboles (Della Ventura 1993; Della Ventura et al. 1996a, 1996b, 1998; Hawthorne et al. 1996a, 1996b, 1997).

Here, we report Fourier-transform infrared (FTIR) and magic-angle spinning nuclear magnetic resonance (MAS NMR) spectroscopic studies of synthetic aluminous tremolites along the tremolite-tschermakite join, and show that IR spectroscopy in the $\mathrm{OH}$-stretching region is a valuable tool in understanding particular features of $\mathrm{Al}$ incorporation in calcic amphibole. 


\section{MATERIALS AND METHODS}

The samples are described by Smelik et al. (1994) and Jenkins et al. (1997). Their nominal compositions, prepared by mixing appropriate amounts of reagent-grade chemicals, vary along the tremolite- $\square \mathrm{Ca}_{2} \mathrm{Mg}_{5} \mathrm{Si}_{8} \mathrm{O}_{22}(\mathrm{OH})_{2}$-magnesiohornblende- $\square \mathrm{Ca}_{2} \mathrm{Mg}_{4} \mathrm{Al}_{2} \mathrm{Si}_{7} \mathrm{O}_{22}(\mathrm{OH})_{2}$ join. In this series, all amphiboles have an empty A-site. Previous workers have reported a reproducible 5-10\% enrichment of $\mathrm{Mg}$ at $\mathrm{M} 4$ in any attempt to synthesize end-member tremolite (Jenkins 1987; Graham et al. 1989; Pawley et al. 1993). Gottschalk et al. (1999) reported electron-microprobe data indicating a range of compositions between 1 and $13 \mathrm{~mol} \%$ cummingtonite solid solution, and infrared results indicating a range between 1 and $6 \mathrm{~mol} \%$ cummingtonite solid solution in tremolite. The details of this issue are obviously difficult to resolve in a quantitative manner. In the samples examined here, the entire join has been shifted $10 \mathrm{~mol} \%$ toward magnesio-cummingtonite (Fig. 1), to obtain the highest amphibole yield possible (Smelik et al. 1994). Thus the M4 composition is nominally fixed at $\mathrm{Ca}_{1.8} \mathrm{Mg}_{0.2}$ apfu (atoms per formula unit). Possible variations of a couple of mol\% cummingtonite in the samples examined do not materially affect the issues addressed here; we are looking at firstorder effects, and such compositional variation is, at most, second-order. The chemical substitution along the series involves major substitution of $\mathrm{Al}$ at both octahedral and tetrahedral sites according to the tschermak-type substitution ${ }^{\mathrm{VI}} \mathrm{Al}+$ ${ }^{\mathrm{IV}} \mathrm{Al} \leftrightarrow{ }^{\mathrm{VI}} \mathrm{Mg}+{ }^{\mathrm{IV}} \mathrm{Si}$ (Table 1).

All run products were obtained at pressures in the range 5.2-13 kbar and temperatures in the range 1096-1133 K, and have been well-characterized by X-ray powder diffraction and electron-microprobe techniques (Smelik et al. 1994; Jenkins et al. 1997). All run products consist of monophase amphibole plus trace amounts $(<1 \%)$ of additional pyroxenes $(\mathrm{Cpx}+\mathrm{Opx})$. Rietveld-refined cell dimensions of the amphiboles vary linearly as a function of composition across the join, suggesting complete solid solution under the experimental conditions used for synthesis.

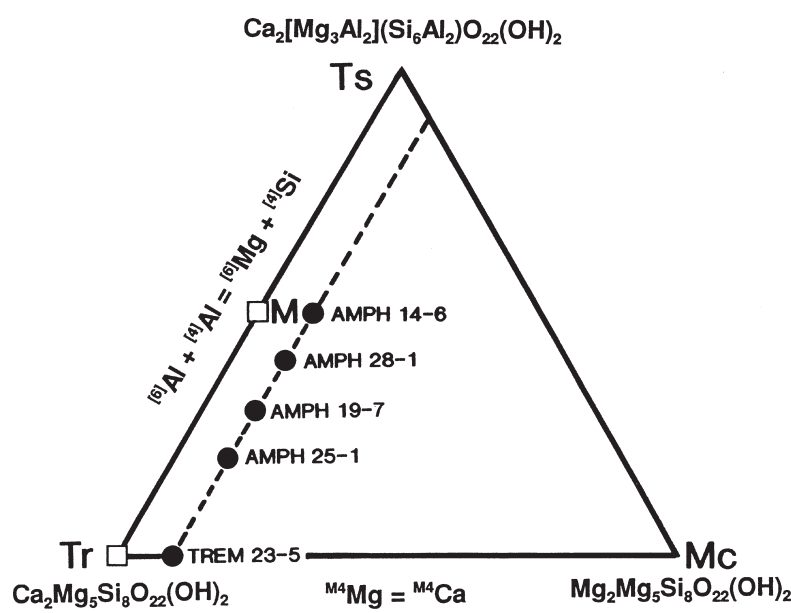

FIGURE 1. The nominal compositions of the starting materials used for amphibole synthesis.
Transmission electron microscopy (TEM) shows that the amphiboles contain (010) chain-multiplicity faults (CMFs). However, their low concentration and the presence of both single- and triple-chain defects suggest that there is not a significant shift of amphibole compositions from the nominal stoichiometries. Electron-microprobe data also show that the synthesized amphiboles are on-composition, except for the more aluminous magnesiohornblende sample (AMPH 14-6), which is close to 90 mol\% magnesiohornblende (Smelik et al. 1994; Jenkins et al. 1997).

\section{Infrared spectroscopy}

FTIR spectra in the $\mathrm{OH}$-stretching region (Figs. 2 and 3) were collected using $\mathrm{KBr}$ disks (Robert et al. 1989). Spectra were recorded on a Nicolet 760 spectrophotometer equipped with a nitrogen-cooled InSb detector and a $\mathrm{CaF}_{2}$ beamsplitter, averaging 64 scans for a nominal resolution of $2 \mathrm{~cm}^{-1}$. Spectra were fitted by interactive optimization followed by least-squares refinement according to the fitting procedure described in detail in Della Ventura et al. (1996a, 1998). A symmetrical Gaussian line-shape was used and all corresponding bands in the series were constrained to have the same widths as those derived from spectra in which the bands are prominent. The refined spectral parameters are given in Table 2. As is common with powder infrared spectra in the principal $\mathrm{OH}$-stretching region, it is difficult-to-impossible to fit a baseline in an objective and yet persuasive manner. When dealing with narrow bands in a restricted energy range, this problem does not adversely affect the fitting procedure. However, when dealing with broad bands over a wide range of energy (as is the case here), a degree of uncertainty is introduced that is not necessarily reflected in the fit to the spectrum. For this reason, we do not attempt a quantitative interpretation of the fitted spectra.

\section{${ }^{27}$ Al MAS NMR spectroscopy}

The ${ }^{27} \mathrm{Al}$ MAS NMR spectrum for AMPH $25-1\left(\mathrm{Al}^{\mathrm{TOT}}=\right.$ 0.8) was obtained using a Chemagnetics CXP-400 multinuclear spectrometer operated at a frequency of 104.2 MHz. The MAS NMR experiment used very short $(<10 \%)$ pulses and a 2 s pulse delay. The very short pulse length ensures that the spectrum is quantitatively reliable. Solid $\mathrm{NaBr}$ was used to set the magic angle accurately using the ${ }^{79} \mathrm{Br}$ NMR resonance. The sample was spun in nitrogen at $13.5 \mathrm{kHz}$ and a spectral width of 40 $\mathrm{kHz}$ was used. A total of 1808 transitions were collected. ${ }^{27} \mathrm{Al}$ chemical shifts are reported relative to $1 \mathrm{M} \mathrm{Al}\left(\mathrm{NO}_{3}\right)_{3}$ solution.

\section{Triple-quantum (3Q) ${ }^{27} \mathrm{Al}$ MAS NMR}

The triple-quantum (3Q MAS NMR) experiment uses three pulses: the first pulse excites the triple-quantum coherence $( \pm 3)$;

TABLE 1. Nominal compositions (apfu) for the synthetic amphiboles

\begin{tabular}{lccclc}
\hline \hline Sample & $\mathrm{A}$ & $\mathrm{M} 4$ & $\mathrm{M} 1, \mathrm{M} 2, \mathrm{M} 3$ & $\mathrm{~T} 1, \mathrm{~T} 2$ & Total Al \\
\hline TREM 23-5 & $\square$ & $\mathrm{Ca}_{1.8} \mathrm{Mg}_{0.2}$ & $\mathrm{Mg}_{5}$ & $\mathrm{Si}_{8}$ & 0 \\
AMPH 25-1 & $\square$ & $\mathrm{Ca}_{1.8} \mathrm{Mg}_{0.2}$ & $\mathrm{Mg}_{4.6} \mathrm{Al}_{0.4}$ & $\mathrm{Si}_{7.6} \mathrm{Al}_{0.4}$ & 0.8 \\
AMPH 19-7 & $\square$ & $\mathrm{Ca}_{1.8} \mathrm{Mg}_{0.2}$ & $\mathrm{Mg}_{4.4} \mathrm{Al}_{0.6}$ & $\mathrm{Si}_{7.4} \mathrm{Al}_{0.6}$ & 1.2 \\
AMPH 28-1 & $\square$ & $\mathrm{Ca}_{1.8} \mathrm{Mg}_{0.2}$ & $\mathrm{Mg}_{4.2} \mathrm{Al}_{0.8}$ & $\mathrm{Si}_{7.2} \mathrm{Al}_{0.8}$ & 1.6 \\
AMPH 14-6 & $\square$ & $\mathrm{Ca}_{1.8} \mathrm{Mg}_{0.2}$ & $\mathrm{Mg}_{4.0} \mathrm{Al}_{1.0}$ & $\mathrm{Si}_{7.0} \mathrm{Al}_{1.0}$ & 2 \\
\hline
\end{tabular}


the second pulse converts the triple-quantum coherence back into observable magnetization $( \pm 1)$; the third pulse equalizes the two coherence pathways (Z-filtering). Details are given in Baltisberger et al. (1996) and references therein. The three pulses had lengths of $3.3 \mu \mathrm{s}, 1 \mu \mathrm{s}$, and $8 \mu \mathrm{s}$, respectively, and a $50 \mathrm{~s}$ pulse delay was used. A total of 96 scans per increment was required for ${ }^{27} \mathrm{Al} 3 \mathrm{Q}$ NMR. To increase peak intensity and shorten the run time, rotor synchronization was used to eliminate spinning sidebands, and the interval between the two first pulses was incremented at $71.26 \mathrm{~ms}$ (corresponding to an MAS rate of $14.0 \mathrm{KHz}$ ). Under these conditions, 128 increments in $\mathrm{t}_{1}$ were sufficient with 96 scans and a 50 s pulse delay. The 3Q MAS NMR experiment lasted about 3 days.

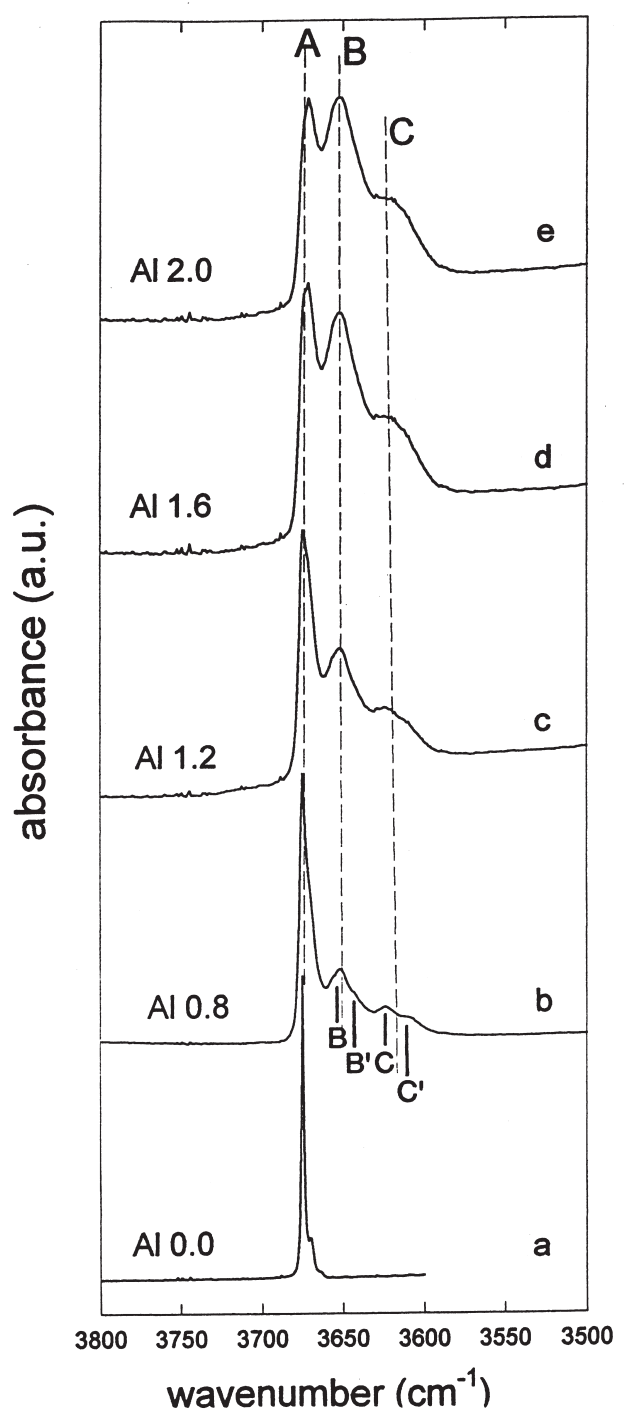

FIGURE 2. Infrared spectra in the principal $\mathrm{OH}$-stretching region for synthetic amphiboles nominally along the join tremolitemagnesiohornblende.

\section{CONFIGURATION NOTATION}

In the amphibole structure, the $\mathrm{OH}$ group is directly bonded to two M1 and one M3 cations, and the $\mathrm{H}$ atom projects into the A-site cavity in which the A-site may be occupied or vacant $(\square)$. The NN (nearest-neighbor) configuration directly around the $\mathrm{OH}$ group may thus be represented by the general symbol M1M1M3-OH- ${ }^{\mathrm{A}} \mathrm{A}$; for ordered end-member tremolite and pargasite, the symbols are $\mathrm{MgMgMg}-\mathrm{OH}-{ }^{\mathrm{A}} \square$ and $\mathrm{MgMgMg}-\mathrm{OH}-{ }^{\mathrm{A}} \mathrm{Na}$, respectively. The M1M1M3 cluster is surrounded by two M2 and one M3 octahedra within the octahedral sheet (Fig. 4) and two T1 tetrahedra within the tetrahedral double-chain. The triplet of cations at M2M3M2 and the

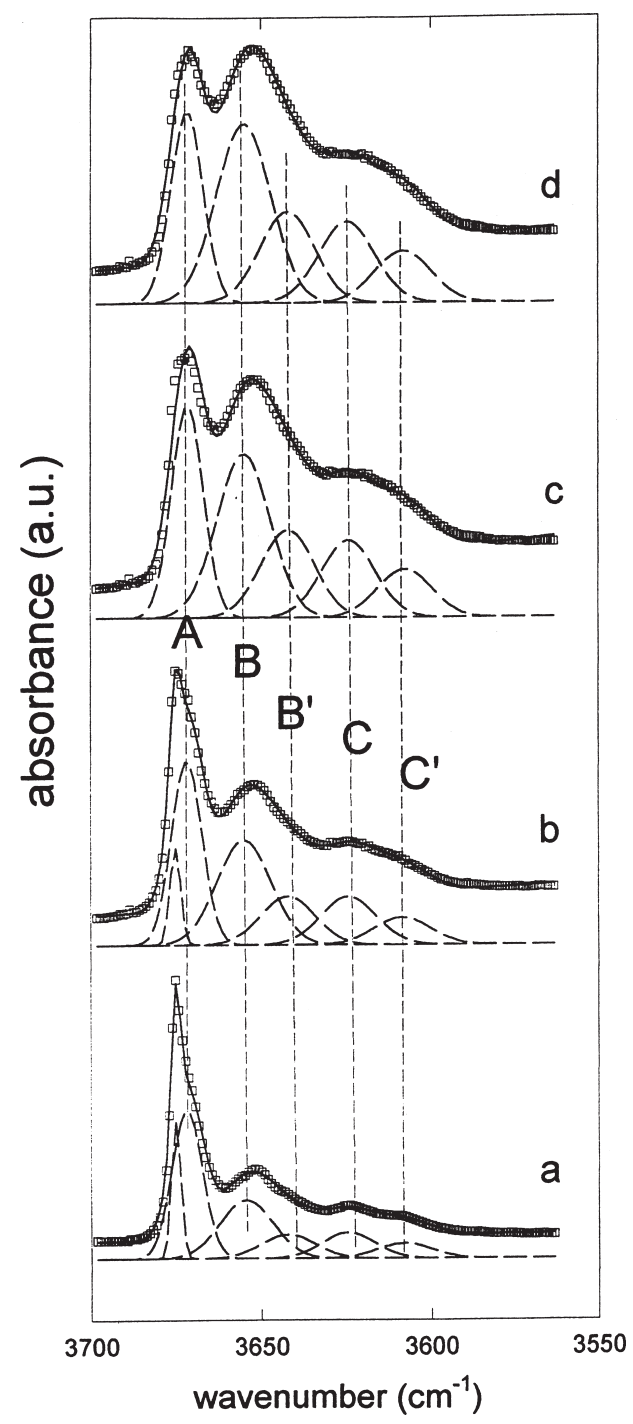

FIGURE 3. Fitted infrared spectra in the principal OH-stretching region for synthetic amphiboles nominally along the join tremolitemagnesiohornblende. The component bands are vertically displaced for clarity; observed intensities are shown by hollow squares, and the line following the observed intensities is the envelope of the sum of the fitted component bands. 
TABLE 2. Positions $\left(\mathrm{cm}^{-1}\right)$, widths $\left(\mathrm{cm}^{-1}\right)$ and relative intensities for the bands in the infrared OH-stretching spectra of synthetic amphiboles along the tremolite-magnesiohornblende join

\begin{tabular}{|c|c|c|c|c|c|c|}
\hline & Parameter & TREM 23-5* & AMPH 25-1 & AMPH 19-7 & AMPH 28-1 & AMPH 14-6 \\
\hline \multirow[t]{3}{*}{$\bar{A}$} & Position & 3675 & 3675.2 & 3675.2 & 3671.5 & 3671.6 \\
\hline & Width & 3.8 & 3.2 & 3.7 & 10.9 & 11 \\
\hline & Intensity & 1 & $0.47 \dagger$ & $0.34 \dagger$ & 0.25 & 0.22 \\
\hline \multirow[t]{3}{*}{$A^{\prime}$} & Position & - & 3672 & 3672 & - & - \\
\hline & Width & - & - & - & - & - \\
\hline & Intensity & - & - & - & - & - \\
\hline \multirow[t]{3}{*}{$B$} & Position & - & 3654.5 & 3655.4 & 3655.1 & 3655.1 \\
\hline & Width & - & 18.6 & 18.6 & 18.3 & 18.7 \\
\hline & Intensity & - & 0.26 & 0.29 & 0.32 & 0.34 \\
\hline \multirow[t]{3}{*}{$\mathrm{B}^{\prime}$} & Position & - & 3642.3 & 3642.3 & 3642.2 & 3642.3 \\
\hline & Width & - & 18.2 & 18.6 & 18.3 & 18.7 \\
\hline & Intensity & - & 0.10 & 0.14 & 0.17 & 0.17 \\
\hline \multirow[t]{3}{*}{ C } & Position & - & 3624.6 & 3624.7 & 3624.3 & 3624.7 \\
\hline & Width & - & 18.5 & 19.2 & 18.7 & 19.4 \\
\hline & Intensity & - & 0.11 & 0.14 & 0.16 & 0.16 \\
\hline \multirow[t]{3}{*}{$C^{\prime}$} & Position & - & 3608 & 3608.5 & 3607.7 & 3608.1 \\
\hline & Width & - & 18.5 & 19.2 & 18.7 & 19.4 \\
\hline & Intensity & - & 0.06 & 0.08 & 0.10 & 0.10 \\
\hline
\end{tabular}

* The cummingtonite component has been neglected.

† The intensity of Band $A=A+A$.

doublet at T1T1 are thus NNN (next-nearest neighbor) cations to $\mathrm{O} 3$. The NNN configuration around the $\mathrm{O} 3$ group may be denoted by adding the cation doublet and triplet to the general symbol introduced above: M1M1M3-O3- ${ }^{\mathrm{A}} \mathrm{A}$ :T1T1M2M3M2. Note that the NN and NNN octahedra within the octahedral sheet have pseudo-trigonal point symmetry. For ideally ordered end-member tremolite and pargasite, the configuration symbols are $\mathrm{MgMgMg}-\mathrm{OH}-{ }^{\mathrm{A}} \square: \mathrm{SiSi}-\mathrm{MgMgMg}$ and $\mathrm{MgMgMg}-\mathrm{OH}-{ }^{\mathrm{A}} \mathrm{Na}: \mathrm{SiAl}-\mathrm{MgMgAl}$, respectively.

\section{Possible ARRANGEMENTS OF NN AND NNN CATIONS}

The NN and NNN arrangements of Figure 4a may be abstracted to the graph shown in Figure 4b. Possible NN and NNN cation arrangements may be derived by coloring the vertices of this graph, where the colors represent occupancy of the sites by different species of cations. The resulting graphs are shown in Figure 5. Some of the configurations shown in Figure 5 will not occur (or be very energetically unfavorable) due to significant deviation from the valence-sum rule (Brown 1981; Hawthorne 1992, 1994, 1997). For example, Hawthorne (1997) has shown that, in pargasite, the preferred configuration from a bond-valence viewpoint involves ${ }^{\mathrm{T} 1} \mathrm{Si}-{ }^{\mathrm{T} 1} \mathrm{Al}$ linked to ${ }^{\mathrm{M} 2} \mathrm{Mg}^{\mathrm{M} 3} \mathrm{Mg}^{\mathrm{M} 2} \mathrm{Al}$ [or ${ }^{\mathrm{M} 2} \mathrm{Mg}^{\mathrm{M} 3} \mathrm{Al}^{\mathrm{M} 2} \mathrm{Mg}$, effectively preventing the occurrence of configurations involving more than one $\mathrm{Al}$ cation at adjacent $\mathrm{M} 2 \mathrm{M} 3 \mathrm{M} 2$ octahedra in the structure. The optimum arrangements from a bondvalence viewpoint are identified in Figure 5.

\section{MAS NMR}

The ${ }^{27} \mathrm{Al}$ MAS NMR spectrum of AMPH 25-1 (Fig. 6) has three distinct maxima at $66.4,3.8$, and $-3.1 \mathrm{ppm}$, respectively. The peak at $66.4 \mathrm{ppm}$ is due to ${ }^{\mathrm{IV}} \mathrm{Al}$, whereas those at 3.8 and -3.1 ppm are due to ${ }^{\mathrm{VI}} \mathrm{Al}$ (Welch et al. 1994; Jenkins et al. 1997). The ${ }^{\mathrm{VI}} \mathrm{Al}$ component of the spectrum extends from about 10 to -50 ppm and clearly exhibits some quadrupolar character. Weak spinning sidebands occur at about $\delta \pm 130 \mathrm{ppm}$. The spectrum is fully

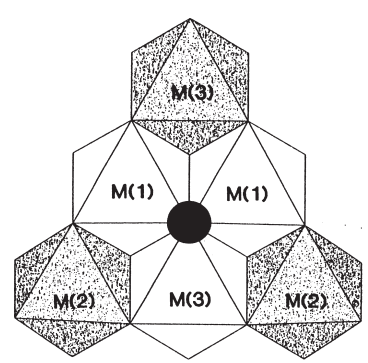

a

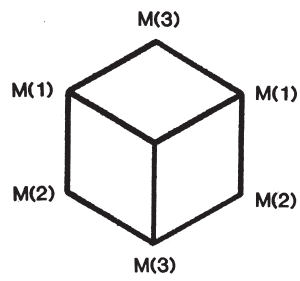

b
FIGURE 4. The NN and NNN arrangements of cation sites around the $\mathrm{O} 3$ site in the $C 2 / m$ amphibole structure: (a) polyhedral representation; (b) simplified graphical representation.

quantitative, as shown by the equal intensities (peak areas) of the ${ }^{\mathrm{IV}} \mathrm{Al}$ and ${ }^{\mathrm{VI}} \mathrm{Al}$ (total) components of the MAS NMR spectrum, as expected for Mg-tschermak exchange. This spectrum is essentially identical to that obtained by Jenkins et al. (1997) for AMPH 25-1, allowing for the different fields used $(9.4 \mathrm{~T}$ vs. 11.7 T). These workers found that the $3.8 \mathrm{ppm}$ peak has $\eta=0$, whereas the -3.1 ppm peak has $\eta=1$. These values are consistent with ${ }^{\mathrm{VI}} \mathrm{Al}$ sites having high and low symmetries, respectively. M1 and M2 sites in $C 2 / m$ amphiboles have symmetry 2 , M3 has symmetry $2 / m$. Hence, the 3.8 ppm peak (low $\eta$ ) is reasonably assigned to M3 and the -3.1 ppm peak is due to M1 or M2. Below, we discuss the choice between M1 and M2.

The 3Q NMR spectrum has an isotropic component that allows Al peaks (Al sites) that overlap in the MAS spectrum to be resolved. This is usually not possible for the single-pulse 


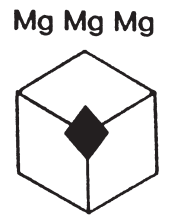

$\mathrm{Mg} \mathrm{Mg} \mathrm{Mg}$

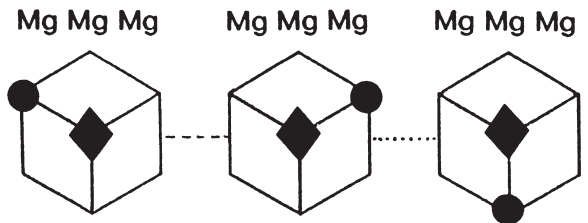

Al Mg Mg $\quad \mathrm{Mg} \mathrm{Al} \mathrm{Mg}$

$\mathrm{Mg} \mathrm{Mg}$ Al

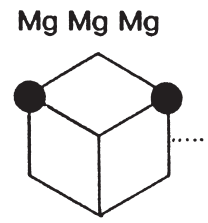

Al Al Mg

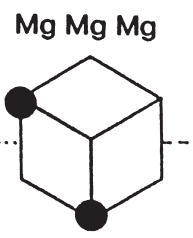

Al Mg Al

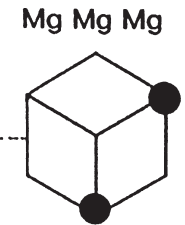

$\mathrm{Mg}$ Al Al

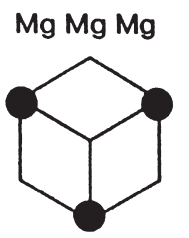

Al Al Al

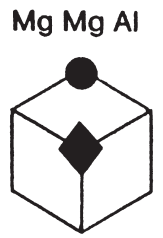

$\mathrm{Mg} \mathrm{Mg} \mathrm{Mg}$

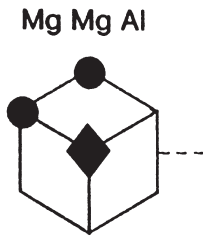

Al $\mathrm{Mg} \mathrm{Mg}$

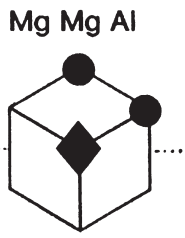

$\mathrm{Mg} \mathrm{Al} \mathrm{Mg}$

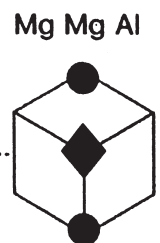

$\mathrm{Mg} \mathrm{Mg} \mathrm{Al}$

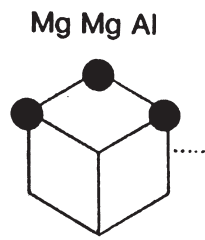

Al Al Mg

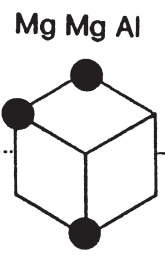

Al $\mathrm{Mg} \mathrm{Al}$

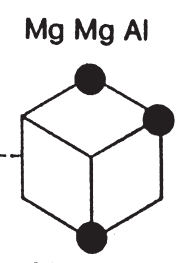

Mg Al Al

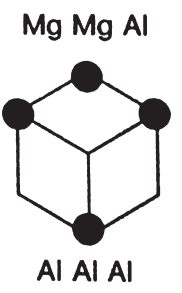

FiguRE 5. Possible $\mathrm{NN}$ and $\mathrm{NNN}$ cation-arrangements around the $\mathrm{O} 3$ site in the $C 2 / \mathrm{m}$ amphibole structure with the constraint that $\mathrm{Al}$ does not occur at the M1 site; undecorated nodes represent $\mathrm{Mg}$, shaded circles represent Al. The NN cation-arrangement is shown above each graph [M1M1M3 = MgMgMg or MgMgAl]; the NNN cation-arrangement is shown below each graph $[\mathrm{M} 2 \mathrm{M} 2 \mathrm{M} 3=\mathrm{MgMgMg}, \mathrm{AlMgMg}\{=\mathrm{MgAlMg}\}$ $=\mathrm{MgMgAl}\}, \mathrm{AlAlMg}\{=\mathrm{AlMgAl}, \mathrm{MgAlAl}\}$ and AlAlAl]. The most-stable arrangements are distinguished by having the central $\mathrm{O} 3$ node occupied by a shaded diamond. Symmetrically equivalent configurations are connected by broken lines, pseudosymmetrically equivalent configurations are connected by dotted lines.

spectrum because of significant quadrupolar components of the spectrum that lead to considerable peak overlap, as we observe for ${ }^{\mathrm{VI}} \mathrm{Al}$. The 3Q spectrum (Fig. 7) clearly resolves two distinct ${ }^{\mathrm{VI}} \mathrm{Al}$ peaks $(\mathrm{FWHM}=2 \mathrm{ppm})$ with isotropic shifts of -44 and -59 ppm, respectively.

\section{INFRARED SPECTRA}

In this series, the spectrum of end-member tremolite (Fig. 2a) represents an obvious reference point as it is now wellcharacterized (Hawthorne et al. 1996a, 1997). It consists of a single very sharp absorption band (full-width at half-height maximum, FWHM, is in the range $3-4 \mathrm{~cm}^{-1}$ ) at $3675 \mathrm{~cm}^{-1}$. This band is assigned to the vibration of an $\mathrm{O}-\mathrm{H}$ dipole bonded to three ${ }^{\mathrm{VI}} \mathrm{Mg}$ cations and directed along $a *$ toward an empty Asite: $\mathrm{MgMgMg}-\mathrm{OH}-{ }^{\mathrm{A}} \square: \mathrm{SiSi}-\mathrm{MgMgMg}$, where $\square$ represents a vacancy. All natural and synthetic tremolites show this band to be asymmetric toward the low-frequency side, suggesting the presence of a second component at around $3670 \mathrm{~cm}^{-1}$. There is strong evidence (Hawthorne et al. 1996a, 1997) that this second band is due to Mg at M4 (a cummingtonite component) that seems ubiquitous in synthetic tremolite (Jenkins 1987; Ahn et al. 1991; Pawley et al. 1993; Maresch et al. 1994; Gottschalk et al. 1998, 1999). The intensity of this band in the spectrum of Fig. 2a ( $\sim 10 \%$ of the total absorption) is more-or-less in accord with the stoichiometry of the tremolite sample examined here.

The introduction of $\mathrm{Al}$ into the tremolite structure correlates with the appearance of two more absorption features (labeled B and C in Fig. 2b to 2e), the intensities of which increase as a function of increasing Al. As is evident in the spectrum of Fig. 2b, the B and C absorptions are both doublets at $3655+$

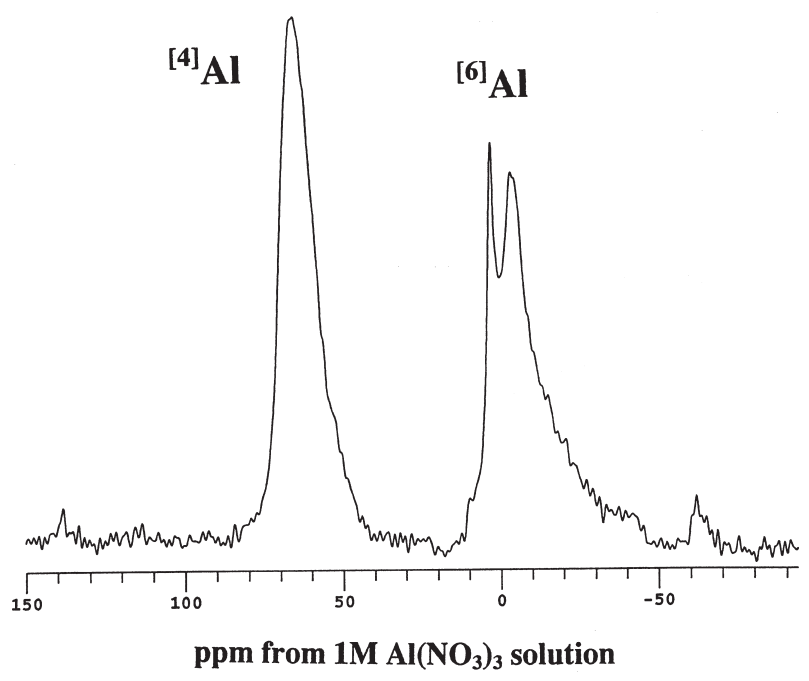

FIGURE 6. ${ }^{27} \mathrm{Al}$ MAS NMR spectrum of AMPH 25-1.

3642 and $3624+3608 \mathrm{~cm}^{-1}$. With increasing $\mathrm{Al}$, the relative intensities of the $\mathrm{B}$ and $\mathrm{C}$ absorptions increase and the individual components of each doublet in Fig. 2b become less apparent. Furthermore, the very sharp band at $3675 \mathrm{~cm}^{-1}$ in the spectrum of tremolite broadens considerably and shifts to slightly lower wavenumber.

\section{EFFECTS OF NNN CATIONS}

Hawthorne et al. (1996a) have shown that variation in the NNN (next-nearest-neighbor)-cation occupancy can also give rise to band splitting in the infrared spectra in the principal $\mathrm{OH}$-stretching region. Pertinent in this regard for the amphib- 


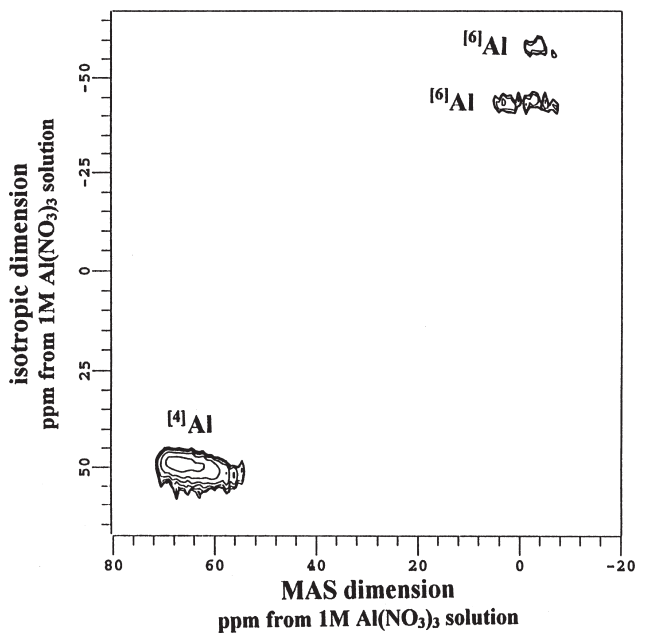

FigURE 7. Triple-quantum (3Q) MAS NMR spectrum of AMPH $25-1$.

oles of this study are the adjacent T1 sites, which may be occupied by $\mathrm{SiSi}$ or $\mathrm{SiAl}$, and the M2M3M2 triplet of sites (Fig. 4), which may be occupied by $\mathrm{Mg}$ and $\mathrm{Al}$ (Fig. 5).

\section{Si and $\mathrm{Al}$ at the $\mathrm{T}$ sites}

In the Al-bearing amphiboles of this work, half the constituent $\mathrm{Al}$ occurs at the $\mathrm{T}$ sites, but details of the relative ordering of Al and Si over the T1 and T2 sites are not known. By analogy with most natural amphiboles, Al should be ordered at the T1 site. However, natural and synthetic high-temperature amphiboles can show considerable disorder of Al over T1 and T2 (Oberti et al. 1995b; Welch et al. 1998; Welch and Knight 1999), but the intermediate synthesis temperatures and unusual composition of the synthetic amphiboles examined here make direct comparison ambiguous. Jenkins et al. (1997) proposed complete disorder of ${ }^{\mathrm{IV}} \mathrm{A} 1$ over the $\mathrm{T} 1$ and $\mathrm{T} 2$ sites, based on ${ }^{29} \mathrm{Si}$ MAS NMR spectra; however, their calculations assume no SRO, a situation that the arguments of Hawthorne (1997) indicate to be most unlikely. Della Ventura et al. (1998) have proposed a mechanism for the interaction between $\mathrm{OH}$ at $\mathrm{O} 3$ and the $\mathrm{O} 7$ atom bridging adjacent $\mathrm{T} 1$ tetrahedra. The $\mathrm{O} 7$ atom acts as a hydrogen bond acceptor for the $\mathrm{OH}$ group at the adjacent $\mathrm{O} 3$ site (Fig. 8). When the $\mathrm{O} 7$ atom links to $\mathrm{Si}$ only [Si-O7-Si], the hydrogen bond is weak; when $\mathrm{O} 7$ links to $\mathrm{Si}$ and $\mathrm{Al}$ [SiO7-Al], the hydrogen bond is much stronger and hence the principal stretching frequency of the $\mathrm{OH}$ group shifts to lower wavenumber. If $\mathrm{Al}$ were to occur at the $\mathrm{T} 2$ site, the $\mathrm{H}$-atom would form a hydrogen bond with the $\mathrm{O} 5$ atom linking the T1 and T2 sites [Si-O5-Al], and hence the shift to lower wavenumber will be similar to that observed when Al occurs at the T1 site. Hence the spectra are unlikely to be affected significantly by any $\mathrm{Al}$ disorder over $\mathrm{T} 1$ and $\mathrm{T} 2$. For simplicity, we will formulate our model assuming all ${ }^{\mathrm{IV}} \mathrm{Al}$ is ordered at the $\mathrm{T} 1$ site in these amphiboles, recognizing that neither the model nor the results should be significantly affected by any disorder of ${ }^{\mathrm{IV}} \mathrm{A} 1$ over $\mathrm{T} 1$ and $\mathrm{T} 2$.

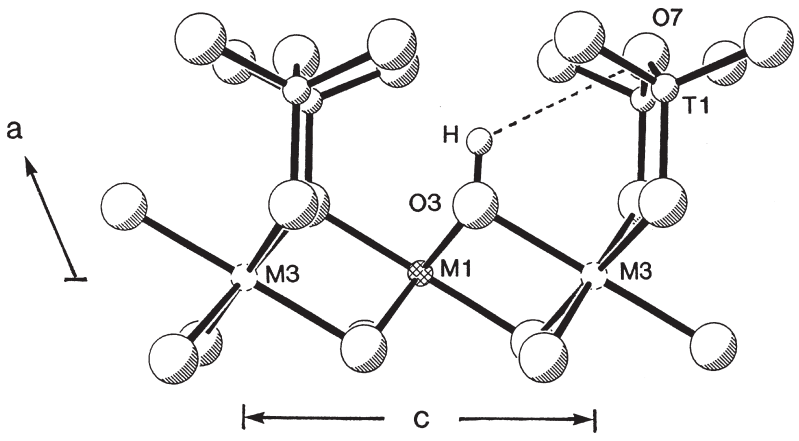

Figure 8. The local environment of the $\mathrm{H}$ atom in the $C 2 / \mathrm{m}$ amphibole structure viewed down (010) with perspective; the T2 sites have been omitted for clarity.

\section{$\mathrm{Mg}$ and $\mathrm{Al}$ at the $\mathrm{M1,2,3}$ sites}

Previous infrared and MAS NMR work on pargasite and $\mathrm{M}^{3+}$-substituted pargasites (Semet 1973; Raudsepp et al. 1987, 1991; Welch et al. 1994) has shown that the trivalent cations in these amphiboles are not completely ordered at M2 but also occur at M1 and/or M3. Oberti et al. (1995a) have shown by single-crystal structure refinement that Al occurs only at the M2 and M3 sites in pargasitic amphiboles. In a neutron powder-diffraction study of synthetic end-member pargasite, Welch and Knight (1999) also found that ${ }^{\mathrm{VI}} \mathrm{A} 1$ occurs at M2 and M3, and not at M1. Our interpretation of the 3Q NMR spectrum of AMPH 25-1 is made in the context of recent diffraction and spectroscopic studies of this and closely related amphiboles (Welch et al. 1994; Jenkins et al. 1997; Oberti et al. 1995a; Welch and Knight 1999). Although the M1 and M2 sites have the same point symmetry, 2, their ligancy is different: M1 is $\mathrm{O}_{4}(\mathrm{OH})_{2}, \mathrm{M} 2$ is $\mathrm{O}_{6}$. Therefore, we would expect these two sites to have distinctly different isotropic shifts. Furthermore, given the large separation (15 ppm) between the isotropic shifts of the ${ }^{\mathrm{VI}} \mathrm{Al}$ peaks in the $3 \mathrm{Q} \mathrm{NMR}$ spectrum, we are confident that the M1 and M2 sites would be resolved in the experiment. There is no suggestion in the $3 \mathrm{Q}$ MAS spectrum of any additional isotropic components to either of these two peaks. Thus, the 3Q MAS spectrum shows conclusively that there are just two different ${ }^{\mathrm{VI}} \mathrm{Al}$ sites, not three. Moreover, the X-ray and neutron-diffraction studies of natural and synthetic Mg-rich hornblendes and pargasites indicate that $\mathrm{Al}$ is ordered at $\mathrm{M} 2$ and $\mathrm{M} 3$ only. We conclude that the two ${ }^{\mathrm{VI}} \mathrm{Al}$ peaks in the 3Q MAS spectrum are most reasonably assigned to Al at M2 and M3, with none at M1. Single-pulse experiments cannot provide such conclusive proof. Thus, in considering the ordering of $\mathrm{Mg}$ and $\mathrm{Al}$ over the NN and NNN cation-sites in the amphibole structure, Mg can occupy the M1, M2, and M3 sites, whereas A1 can occupy only the M2 and M3 sites. These observed longrange ordering patterns constrain possible local configurations about the $\mathrm{O} 3$ site.

\section{BAND ASSIGNMENT}

If magnesiohornblende, $\square \mathrm{Ca}_{2} \mathrm{Mg}_{4} \mathrm{AlSi}_{7} \mathrm{AlO}_{22}(\mathrm{OH})_{2}$, were to show the maximum long- range order possible, then $\mathrm{M} 1=\mathrm{M} 2$ $=\mathrm{Mg}, \mathrm{M} 3=\mathrm{Al}$; this arrangement will have two local configurations around the $\mathrm{O} 3$ site: $\mathrm{MgMgAl}-\mathrm{OH}-{ }^{\mathrm{A}} \square-\mathrm{SiSi}-\mathrm{MgAlMg}$ 
and $\mathrm{MgMgAl}-\mathrm{OH}-^{\mathrm{A}} \square-\mathrm{SiAl}-\mathrm{MgAlMg}$, and would show two bands in its infrared spectrum in the principal $\mathrm{OH}$-stretching region. If magnesiohornblende were to have the long-range ordering pattern $\mathrm{M} 1=\mathrm{M} 3=\mathrm{Mg}, \mathrm{M} 2=0.5 \mathrm{Al}+0.5 \mathrm{Mg}$, this arrangement will have the following two local configurations around the $\mathrm{O} 3$ site: $\mathrm{MgMgMg}-\mathrm{OH}-{ }^{\mathrm{A}} \square-\mathrm{SiSi}-\mathrm{MgMgAl}$ and $\mathrm{MgMgMg}-\mathrm{OH}-^{\mathrm{A}} \square-\mathrm{SiAl}-\mathrm{MgMgAl}$, and would show two bands in its infrared spectrum in the principal $\mathrm{OH}$-stretching region. Previous interpretations of the $\mathrm{OH}$-stretching spectra of aluminous amphiboles (Semet 1973; Raudsepp et al. 1987, Della Ventura et al. 1998) have assigned two broad bands to configurations involving M1M1M3 $=\mathrm{MgMgMg}$ and $\mathrm{MgMgAl}$. However, inspection of Fig. 2 indicates that there are additional bands in the spectra presented here, together with fine structure in the major bands, indicating that there is more disorder in these amphiboles than an ideal ordered model would indicate (Della Ventura et al. 1998).

\section{BANDS A AND A'}

The A band is the only feature (neglecting the minor cummingtonite component) in the spectrum of TREM 23-5, and can be assigned unambiguously to the configuration $\mathrm{MgMgMg}-\mathrm{OH}-{ }^{\mathrm{A}} \square-\mathrm{SiSi}-\mathrm{MgMgMg}$. In end-member tremolite, this band is extremely sharp, whereas in amphiboles with significant $\mathrm{Al}$, it splits into two components, one of which shifts to slightly lower frequency, but still remains a major feature of the spectrum (Fig. 2). It is instructive to consider the spectrum of magnesiohornblende (AMPH 14-6): $\square\left(\mathrm{Ca}_{1.8} \mathrm{Mg}_{0.2}\right)\left(\mathrm{Mg}_{4} \mathrm{Al}\right)$ $\left(\mathrm{Si}_{7} \mathrm{Al}\right) \mathrm{O}_{22}(\mathrm{OH})_{2}$. Inspection of Figure 5 shows that there are two possibilities for the occupancy of the M2M3M2 trimers by $\mathrm{Al}:$ (1) all $\mathrm{M} 2 \mathrm{M} 3 \mathrm{M} 2$ trimers contain one $\mathrm{Al}$ and two $\mathrm{Mg}$ (MgAlMg or $\mathrm{MgMgAl}$ ) or (2) trimers contain different amounts of $\mathrm{Al}$ and $\mathrm{Mg}(\mathrm{MgMgMg}$ and $\mathrm{AlMgAl}$ or MgAlAl). From a bond-valence viewpoint, situation 1 is more preferable as situation 2 provides too much incident bond-valence to the $\mathrm{O} 1$ anions coordinating the $\mathrm{M} 3$ site. This being the case, the configurations $\mathrm{MgMgMg}-\mathrm{OH}-{ }^{\mathrm{A}} \square-\mathrm{SiSi}-\mathrm{MgMgMg}$ and $\mathrm{MgMgMg}-\mathrm{OH}-{ }^{\mathrm{A}} \square-\mathrm{SiAl}-\mathrm{MgMgMg}$ are unlikely to occur in magnesiohornblende, and band $\mathrm{A}^{\prime}$ in the magnesiohornblende spectrum will be due to a different configuration than band $\mathrm{A}^{\prime}$ in the tremolite spectrum.

\section{BANDS B, B', C, AND C'}

These bands must be assigned to configurations involving $\mathrm{Al}$. There are four distinct substitutions involving $\mathrm{Al}$ in these amphiboles: $(1)^{\mathrm{M} 3} \mathrm{Al} \rightarrow{ }^{\mathrm{M} 3} \mathrm{Mg}$ at the $\mathrm{NN}$ sites; $(2)^{\mathrm{T}} \mathrm{Al} \rightarrow{ }^{\mathrm{T}} \mathrm{Si}$; (3) ${ }^{\mathrm{M} 2} \mathrm{Al} \rightarrow{ }^{\mathrm{M} 2} \mathrm{Mg}$; and (4) ${ }^{\mathrm{M} 3} \mathrm{Al} \rightarrow{ }^{\mathrm{M} 3} \mathrm{Mg}$ at NNN sites. However, substitutions 3 and 4 are pseudosymmetrically equivalent, and hence will not give rise to different bands. Thus we cannot distinguish between M2M3M2 $=\mathrm{MgMgAl}$ and $\mathrm{MgAlMg}$. Substitution 1 involves a change in bond-valence of 0.17 valence units (v.u.) ( $0.50-0.33$ v.u.) directly at the $\mathrm{O} 3$ anion, and hence is expected to cause the largest shift in the principal $\mathrm{OH}$-stretching frequency. Substitution 2 involves a change of 0.25 v.u. at $\mathrm{O} 1$, a NN anion to O3, whereas substitution 3 involves a change of 0.17 v.u. at $\mathrm{O} 1$; hence substitution 2 is expected to cause a larger frequency shift than substitution 3 .

From the results of Raudsepp et al. (1987), we may make the following statement: replacement of $\mathrm{Mg}$ by $\mathrm{Al}$ at $\mathrm{M} 3$ (i.e., substitution 1) causes a downward frequency shift of $\sim 30-35$ $\mathrm{cm}^{-1}$. The results of Hawthorne et al. (1996a) indicate that replacement of $\mathrm{Si}$ by $\mathrm{Al}$ at $\mathrm{T} 1$ (i.e., substitution 2) causes a downward frequency shift of $\sim 20 \mathrm{~cm}^{-1}$. These two results provide us with a basis for assigning bands in the spectra of Figure 2.

Band A at $3675 \mathrm{~cm}^{-1}$ is $\mathrm{MgMgMg}-\mathrm{SiSi}-\mathrm{MgMgMg}$; substitution 2 should produce a band corresponding to $\mathrm{MgMgMg}-$ SiAl-MgMgMg at $3655 \mathrm{~cm}^{-1}$, which corresponds to band B (Table 2); substitution 1 should produce a band, corresponding to $\mathrm{MgMgAl}-\mathrm{SiSi}-\mathrm{MgMgMg}$ at $3645 \mathrm{~cm}^{-1}$ which corresponds reasonably well with band $\mathrm{B}^{\prime}$ (Table 2); combination of substitutions 1 and 2 should produce a band corresponding to $\mathrm{MgMgAl}-\mathrm{SiAl}-\mathrm{MgMgMg}$ at $3625 \mathrm{~cm}^{-1}$, corresponding to band C (Table 2).

The remaining bands should then be due to substitution 3 , which should produce smaller shifts than substitutions 1 and 2 (see above discussion). Table 3 shows the resulting band assignments. It is notable that substitution 3 does not produce a constant shift in frequency: from configurations $1 \rightarrow 2,3 \rightarrow 4$, $5 \rightarrow 6$, and $7 \rightarrow 8$, the frequency shifts are $4,13,17$, and 17 $\mathrm{cm}^{-1}$, respectively, for the ${ }^{\mathrm{M} 2} \mathrm{Al} \rightarrow{ }^{\mathrm{M} 2} \mathrm{Mg}$ substitution. Apparently the local relaxations associated with this substitution distribute themselves differently in the different local configurations.

\section{LONG-RANGE ORDER IN AL-BEARING AMPHIBOLES}

Recent results of X-ray crystal-structure refinement have established general patterns of long-range order of ${ }^{\mathrm{IV}} \mathrm{Al}$ in calcic amphiboles (Oberti et al. 1995b): when ${ }^{\mathrm{IV}} \mathrm{Al} \leq 2 \mathrm{apfu}$, it is completely ordered at $\mathrm{T} 1$ in most metamorphic occurrences and partly disordered in some higher temperature igneous parageneses. The amphiboles of this study were synthesized in the temperature range $1096-1133 \mathrm{~K}\left(823-860{ }^{\circ} \mathrm{C}\right)$, and ${ }^{\mathrm{IV}} \mathrm{Al}$ is likely to be ordered predominantly at $\mathrm{T} 1$.

Regarding ${ }^{\mathrm{VI}} \mathrm{Al}$, Raudsepp et al. (1987) and Welch et al. (1994) have shown that ${ }^{\mathrm{VI}} \mathrm{Al}$ cannot be completely ordered at the M2 site in synthetic pargasite, and Oberti et al. (1995a) and Welch and Knight (1999) have shown that ${ }^{\mathrm{VI}} \mathrm{Al}$ is partly disordered over the M2 and M3 sites in Mg-rich pargasite. It is apparent from the infrared results given here and the NMR results of Jenkins et al. (1997) that ${ }^{\mathrm{VI}} \mathrm{Al}$ in magnesiohornblende is also disordered over the $\mathrm{M}$ sites. Indeed, comparison of the infrared spectra obtained here with the analogous infrared spectra of the synthetic potassium-richterite-pargasite series of Della

TABLE 3. Possible configurations around the $\mathrm{OH}$ group in synthetic amphiboles of the tremolite-magnesiohornblende series, together with the assigned bands and observed band frequencies

\begin{tabular}{|c|c|c|c|}
\hline No. & Configuration & Observed & $\begin{array}{c}\text { Band } \\
\text { frequency }\left(\mathrm{cm}^{-1}\right)\end{array}$ \\
\hline 1 & [MgMgMg]-SiSi-MgMgMg & 3675 & $A$ \\
\hline $2^{*}$ & [MgMgMg]-SiSi-MgMgAl & 3671 & $A^{\prime}$ \\
\hline 3 & [MgMgMg]-SiAl-MgMgMg & 3655 & $\mathrm{~B}$ \\
\hline $4^{*}$ & [MgMgMg]-SiAl-MgMgAl & 3642 & $\mathrm{~B}^{\prime}$ \\
\hline 5 & [MgMgAl]-SiSi-MgMgMg & 3642 & $\mathrm{~B}^{\prime}$ \\
\hline $6^{*}$ & [MgMgAl]-SiSi-MgMgAl & 3625 & $\mathrm{C}$ \\
\hline 7 & [MgMgAl]-SiAl-MgMgMg & 3625 & $\mathrm{C}$ \\
\hline $8^{*}$ & [MgMgAl]-SiAl-MgMgAl & 3608 & $\mathrm{C}^{\prime}$ \\
\hline
\end{tabular}


Ventura et al. (1998) suggests that ${ }^{\mathrm{V}} \mathrm{Al}$ behaves in a similar fashion in both series, i.e., partly disorders over the M2 and M3 sites.

\section{Quantitative considerations}

Hawthorne et al. (1996b) discussed some of the issues affecting band intensity in the principal $\mathrm{OH}$-stretching region of the infrared. A key factor in this regard is the variation in transition moment as a function of transition energy; unless its relation is known, band intensities cannot be converted accurately to site populations. This relation is not well-known for amphiboles. It has been measured by Skogby and Rossman (1991) for single crystals of miscellaneous amphiboles, and by Hawthorne et al. (1997) for powder spectra of the series potassicrichterite-tremolite. In addition, Della Ventura et al. (1996b) have shown that it is not a factor in powder spectra of synthetic ( $\mathrm{Ni}, \mathrm{Mg}, \mathrm{Co})$-potassicrichterite. Thus it is apparent that we do not yet understand this behavior sufficiently to derive accurate site-populations.

Another issue affecting derivation of site populations (Hawthorne et al. 1995) for the amphiboles examined here relates to accidental band degeneracy. As indicated in Table 3, five bands $\left[\left(\mathrm{A}+\mathrm{A}^{\prime}\right), \mathrm{B}, \mathrm{B}^{\prime}, \mathrm{C}, \mathrm{C}^{\prime}\right]$ are caused by eight configurations. According to the configurations listed in Table 3,

$$
\begin{aligned}
& { }^{\mathrm{T} 1} \mathrm{Al}=2\left(I^{3}+I^{4}+I^{7}+I^{8}\right) / \sum_{\mathrm{n}=1}^{8} I^{\mathrm{n}} \\
& { }^{\mathrm{M} 3} \mathrm{Al}=2\left(I^{5}+I^{6}+I^{7}+I^{8}\right) / \sum_{\mathrm{n}=1}^{8} I^{\mathrm{n}}
\end{aligned}
$$

According to the band assignment of Table 3, band B' corresponds to configurations 4 and 5 , and hence we do not know $I^{4}$ or $I^{5}$, we only know $I^{4}+I^{5}$. This means that we cannot calculate ${ }^{\mathrm{M} 3} \mathrm{Al}$ or ${ }^{\mathrm{T} 1} \mathrm{Al}$ as $I^{4}$ or $I^{5}$ only appears in the numerators of the above equations.

\section{SHORT-RANGE ORDER IN MAGNESIOHORNBLENDE}

The number of component bands observed in the infrared spectra corresponds closely to the number of bands predicted on the basis of local configurations that most closely satisfy the valence-sum rule (Hawthorne 1997), indicating that NNN arrangements in amphiboles can significantly affect the principal OH-stretching frequency. Furthermore, this correspondence provides experimental support for the prediction of Hawthorne (1997) that amphiboles are strongly short-range ordered, and that this ordering is induced by short-range (local) bond-valence requirements.

\section{THE OCCURRENCE OF ${ }^{\mathrm{VI}}$ AL AT THE M3 SITE}

As noted above, Oberti et al. (1995a) showed that ${ }^{\mathrm{VI}} \mathrm{Al}$ is partly disordered over the M2 and M3 sites in Mg-rich pargasite; Welch and Knight (1999) found the same pattern of order in synthetic end-member pargasite. Hawthorne (1997) suggested that the occurrence of ${ }^{\mathrm{VI}} \mathrm{Al}$ at $\mathrm{M} 2$ and ${ }^{\mathrm{IV}} \mathrm{Al}$ at $\mathrm{T} 1$ are locally connected via short-range bond-valence requirements of the anions common to both sites; this short-range arrangement is shown diagrammatically in Figure 9. When the $\mathrm{O} 1$ (and O1')
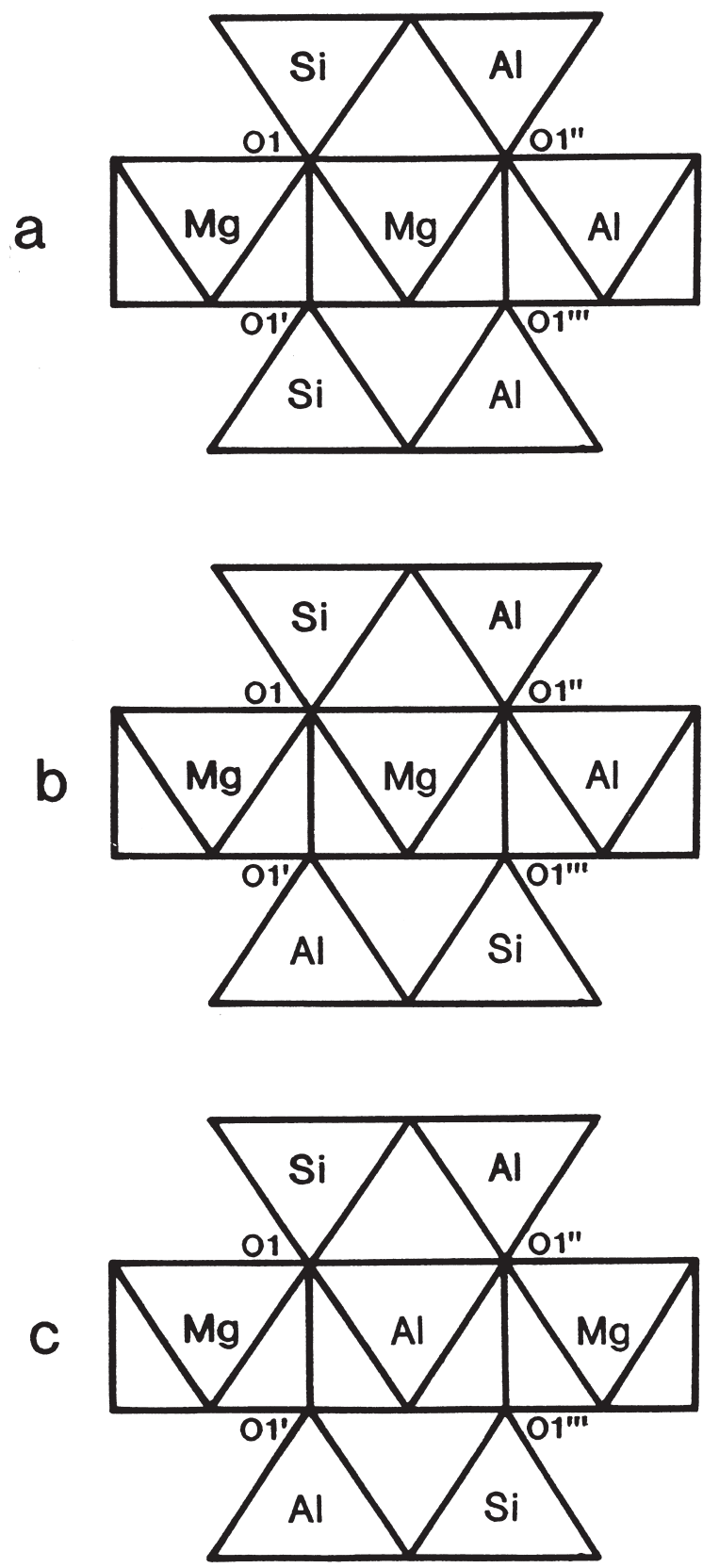

FigURE 9. Possible short-range arrangements involving $\mathrm{Si}$ and $\mathrm{Al}$ at the $\mathrm{T} 1$ site and $\mathrm{Mg}$ and $\mathrm{Al}$ at the $\mathrm{M} 2$ and $\mathrm{M} 3$ sites in the $C 2 / m$ amphibole structure.

anion is linked to ${ }^{\mathrm{M} 2} \mathrm{Mg}$ and ${ }^{\mathrm{T} 1} \mathrm{Si}$, the incident bond-strength at this anion is $1 / 3 \times 3+1=2 \mathrm{v} . \mathrm{u}$. When the same anion is linked to ${ }^{\mathrm{M} 2} \mathrm{Al}$ and ${ }^{\mathrm{T} 1} \mathrm{Al}$ (as for anions $\mathrm{O} 1 "$ and $\mathrm{O} 1$ "' in Fig. 9a), the incident bond-strength is $1 / 3 \times 2+1 / 2+3 / 4=1.92$ v.u., also close to the ideal value of 2 v.u. However, the local arrangement in Figure 9a involves the two $\mathrm{Si}-\mathrm{Al}$ arrangements being related (in projection) by a horizontal mirror plane; there is no space-group constraint on this arrangement, and it is suscep- 
tible to short-range order-disorder. The alternative arrangement is shown in Figure 9b, in which the two $\mathrm{Si}-\mathrm{Al}$ arrangements are now related (in projection) by a twofold rotation axis orthogonal to the figure (Fig. 9b). If ${ }^{\mathrm{VI}} \mathrm{Al}$ occurs at $\mathrm{M} 2$, the bondvalence sum incident at O1 (2 v.u.) and O1" (1.92 v.u.) are in accord with the analogous values in Figure 9a, whereas the bond-valence sums incident at $\mathrm{O} 1^{\prime}$ and $\mathrm{O} 1$ '" are $1 / 3 \times 3+3 / 4=$ 1.75 v.u. and $1 / 3 \times 2+1 / 2+1=2.17$ v.u., respectively. The large bond-valence deficiency at $\mathrm{O} 1$ ' can be alleviated by occurrence of ${ }^{\mathrm{VI}} \mathrm{Al}$ at $\mathrm{M} 3$ rather than $\mathrm{M} 2$ (Fig. 9c), producing bondvalence sums of 2.17 v.u. at $\mathrm{O} 1$ and $\mathrm{O} 1{ }^{\prime \prime \prime}$ and 1.92 v.u. at O1' and $\mathrm{O} 1 "$. Thus the chain configurations above and below the octahedral strip seem to be implicated in the occurrence of Al$\mathrm{Mg}$ disorder over the M2 and M3 sites.

\section{ACKNOWLEDGMENTS}

F.C.H. was supported by a Research Grant from the Natural Sciences and Engineering Research Council of Canada; G.D.V. was supported by Cofinanziamento MURTS 1997-Relazione tra struttura e proprietà dei minerali: analisi ed applicazioni. D.M.J. was funded by NSF grant EAR-9628212.

\section{REFERENCES CITED}

Ahn, J.H., Cho, M., Jenkins, D.M., and Buseck, P.R. (1991) Structural defects in synthetic tremolitic amphiboles. American Mineralogist, 76, 1811-1823.

Baltisberger, J.H., Xu, Z., Stebbins, J.F., Wang, S.H., and Pines, A. (1996) Triplequantum two dimensional ${ }^{27}$ Al Magic-Angle Spinning Nuclear Magnetic Resonance Spectroscopy study of aluminosilicate and aluminate crystals and glasses. Journal of the American Chemical Society, 118, 7209-7214.

Brown, I.D. (1981) The bond-valence method: an empirical approach to chemical structure and bonding. In M. O'Keeffe and A. Navrotsky, eds., Structure and Bonding in Crystals II, 1-30. Academic Press, New York.

Cho, M. and Ernst, W.G. (1991) An experimental determination of calcic amphibole solid solution along the join tremolite-tschermakite. American Mineralogist, 76, 985-1001.

Della Ventura, G. (1993) Recent developments in the synthesis and characterization of amphiboles. Synthesis and crystal-chemistry of richterites. Trends in Mineralogy, 1, 153-192.

Della Ventura, G., Robert, J.-L., Hawthorne, F.C., and Prost, R. (1996a) Short-range disorder of $\mathrm{Si}$ and $\mathrm{Ti}$ in the tetrahedral double-chain unit of synthetic Ti-bearing potassium-richterite. American Mineralogist, 81, 56-60.

Della Ventura, G., Robert, J.-L., and Hawthorne, F.C. (1996b) Infrared spectroscopy of synthetic (Ni,Mg,Co)-potassium-richterite. In M.D. Dyar, C. McCammon and M.W. Schaefer, Eds., Mineral Spectroscopy: A Tribute to Roger G. Burns, p. 55-63. The Geochemical Society Special Publication No. 5.

Della Ventura, G., Hawthorne, F.C., Robert, J.-L., Delbove, F., Welch, M. F., and Raudsepp, M. (1998) Short-range order of cations in synthetic amphiboles along the richterite-pargasite join. European Journal of Mineralogy, 11, 79-94.

Gottschalk, M., Najorka, J., and Andrut, M. (1998) Structural and compositional characterization of synthetic $(\mathrm{Ca}, \mathrm{Sr})$-tremolites and $(\mathrm{Ca}, \mathrm{Sr})$-diopsides. Physics and Chemistry of Minerals, 25, 415-428.

Gottschalk, M., Andrut, M., and Melzer, S. (1999) The determination of the cummingtonite content of synthetic tremolite. European Journal of Mineralogy, 11, 967-982.

Graham, C.M., Maresch, W.V., Welch, M.D., and Pawley, A.R. (1989) Experimental studies on amphiboles: a review with thermodynamic perspectives. European Journal of Mineralogy, 1, 535-555.

Hammarstrom, J.M. and Zen, E-an (1986) Aluminum in hornblende: an empirical igneous geobarometer. American Mineralogist, 71, 1297-1313.

Hawthorne, F.C. (1983) Crystal chemistry of the amphiboles. Canadian Mineralogist, $21,174-481$.

(1992) The role of $\mathrm{OH}$ and $\mathrm{H}_{2} \mathrm{O}$ in oxide and oxysalt minerals. Zeitschrift für Kristallographie, 201, 183-206.

- (1994) Structural aspects of oxides and oxysalt crystals. Acta Crystallographica, B50, 481-510.

- (1997) Short-range order in amphiboles: a bond-valence approach. Canadian Mineralogist, 35, 201-216.

Hawthorne, F.C., Ungaretti, L., and Oberti, R. (1995) Site populations in minerals: Terminology and presentation of results of crystal-structure refinement. Canadian Mineralogist, 33, 907-911.

Hawthorne, F.C., Della Ventura, G., and Robert, J.-L. (1996a) Short-range order of
$(\mathrm{Na}, \mathrm{K})$ and $\mathrm{Al}$ in tremolite: An infrared study. American Mineralogist, 81, 782784.

(1996b) Short-range order and long-range order in amphiboles: a model for the interpretation of infrared spectra in the principal $\mathrm{OH}$-stretching region. In M.D. Dyar, C. McCammon and M.W. Schaefer, Eds., Mineral Spectroscopy: A Tribute to Roger G. Burns, p. 49-54. The Geochemical Society Special Publication No. 5.

Hawthorne, F.C., Della Ventura, G., Robert, J.-L., Welch, M.D., Raudsepp, M., and Jenkins, D.M. (1997) A Rietveld and infrared study of synthetic amphiboles along the potassium-richterite-tremolite join. American Mineralogist, 82, 708716.

Holland T.J.B. and Richardson, S.W. (1979) Amphibole zonation in metabasites as a guide to the evolution of metamorphic zonation in metabasites. Contributions to Mineralogy and Petrology, 70, 143-148.

Hollister, L.S., Grissom, G.C., Peters, E.K., Stowell, H.H., and Sisson, V.B. (1987) Confirmation of the empirical correlation of $\mathrm{Al}$ in hornblende with pressure of solidification of calc-alkaline plutons. American Mineralogist, 72, 231-239.

Jenkins, D.M. (1987) Synthesis and characterization of tremolite in the system $\mathrm{H}_{2} \mathrm{O}-$ $\mathrm{CaO}-\mathrm{MgO}-\mathrm{SiO}_{2}$. American Mineralogist, 72, 707-715.

(1988) Experimental study of the join tremolite-tschermakite: a reivestigation. Contributions to Mineralogy and Petrology, 99, 392-400.

(1994) Experimental reversal of the aluminum content in tremolitic amphiboles in the system $\mathrm{H}_{2} \mathrm{O}-\mathrm{CaO}-\mathrm{MgO}-\mathrm{Al}_{2} \mathrm{O}_{3}-\mathrm{SiO}_{2}$. American Journal of Science, 294, 593-620.

Jenkins, D.M., Sherriff, B.L., Cramer, J., and Xu, Z. (1997) Al, Si, and Mg occupancies in tetrahedrally and octahedrally coordinated sites in synthetic aluminous tremolite. American Mineralogist, 82, 280-290.

Kohn, M.J. and Spear, F.S. (1990) Two new geobarometers for garnet amphibolites, with applications to southeastern Vermont. American Mineralogist, 75, 89-96.

Mader, U.K. and Berman, R.G. (1992) Amphibole thermobarometry: a thermodynamic approach. Current Research, part E. Geological Survey of Canada, Paper 92-1E, 393-400.

Maresch, W.V., Czank, M., and Schreyer, W. (1994) Growth mechanisms, structural defect and composition of synthetic tremolite: what are the effects on macroscopic properties? Contributions to Mineralogy and Petrology, 118, 297-313.

Oberti, R., Hawthorne, F.C., Ungaretti, L., and Cannillo, E. (1995a) ${ }^{\mathrm{VI}} \mathrm{Al}$ disorder in amphiboles from mantle peridotites. Canadian Mineralogist, 33, 867-878.

Oberti, R., Ungaretti, L., Cannillo, E., Hawthorne, F.C., and Memmi, I. (1995b) Temperature-dependent $\mathrm{Al}$ order-disorder in the tetrahedral double chain of $\mathrm{C} 2 /$ $\mathrm{m}$ amphiboles. European Journal of Mineralogy, 7, 1049-1063.

Pawley, A.R., Graham, C.M., and Navrotsky, A. (1993) Tremolite-richterite amphiboles: synthesis, compositional and structural characterization and thermochemistry. American Mineralogist, 78, 23-35.

Raudsepp, M., Turnock, A.C., Hawthorne, F.C., Sheriff, B.L., and Hartman, J.S. (1987) Characterization of synthetic pargasitic amphiboles $\left(\mathrm{NaCa}_{2}\right.$ $\left.\mathrm{Mg}_{4} \mathrm{M}^{3+} \mathrm{Si}_{6} \mathrm{Al}_{2} \mathrm{O}_{22}(\mathrm{OH}, \mathrm{F})_{2} ; \mathrm{M}^{3+}=\mathrm{Al}, \mathrm{Cr}^{3+}, \mathrm{Ga}, \mathrm{Fe}^{3+}, \mathrm{Sc}, \mathrm{In}\right)$ by infrared spectroscopy, Rietveld structure refinement and ${ }^{27} \mathrm{Al}$ and ${ }^{29} \mathrm{Si}$ MAS NMR spectroscopy. American Mineralogist, 72, 580-593.

Raudsepp, M., Turnock, A.C., and Hawthorne, F.C. (1991) Amphibole synthesis at low pressure: what grows and what doesn't. European Journal of Mineralogy, 3, 983-1004.

Semet, M.P. (1973) A crystal-chemical study of synthetic magnesiohastingsite. American Mineralogist, 58, 480-494.

Skogby, H. and Rossman, G.R. (1991): The intensity of amphibole OH bands in the infrared spectrum. Physics and Chemistry of Minerals, 18, 64-68.

Smelik, E.A., Jenkins, D.M., and Navrotsky, A. (1994) A calorimetric study of synthetic amphiboles along the tremolite-tschermakite join and the heats of formation of magnesiohornblende and tschermakite. American Mineralogist, 79, 11101122 .

Spear, F.S. (1981) An experimental study of horneblende stability and compositional variability in amphibolite. American Journal of Science, 281, 697-734.

Triboulet, C. and Audren, C. (1988) Controls on P-T-t deformation path from amphibole zonation during progressive metamorphism of basic rocks (estuary of the River Vilaine, south Brittany, France). Journal of Metamorphic Geology, 6, $117-133$.

Welch, M.D. and Knight, K.S. (1999) A neutron powder diffraction study of cation ordering in high-temperature synthetic amphiboles. European Journal of Mineralogy, 11, 321-331.

Welch, M.D., Kolodziejski, W., and Klinowski, J. (1994) A multinuclear study of synthetic pargasite. American Mineralogist, 79, 261-268.

Welch, M.D., Liu, S., and Klinowski, J. (1998) ${ }^{29}$ Si MAS NMR systematics of calcic and sodic- calcic amphiboles. American Mineralogist, 83, 85-96.

MANUSCRIPT RECEIVED SEPTEMBER 13, 1999

MANUSCRIPT ACCEPTED JULY 24, 2000

PAPER HANDLED BY BRIAN PHILLIPS 